be observed. The parents and sibs of the present case are, like the propositus, in the 75 th centile for height. The retarded bone age of the propositus suggests that his ultimate height may be greater than that of his normal sibs.

The mechanism by which this patient received his extra $\mathrm{Y}$ chromosomes is not clear. The most likely explanation appears to be the one originally proposed by Townes et al (1965), namely, nondisjunction in spermatogonial mitosis followed by a 2nd non-disjunction of one of the $\mathrm{Y}$ chromosomes in meiosis resulting in the formation of a sperm bearing $3 \mathrm{Y}$ chromosomes.

The introduction of fluorescent and heterochromatin staining techniques has opened the door to further advances in the field of cytogenetics. The diagnosis of the present case was dependent upon these methods. Additional cases of 48,XYYY will almost certainly be recognized in the screening surveys utilizing fluorescent staining of blood smears, possibly among male patients with mild psychomotor retardation, simian creases, and evidence of retarded bone maturation.

Meanwhile the intention is to follow the growth, development, and personality pattern of this boy as he matures and later note gonadal function and meiotic chromosome morphology. Hopefully this will help increase understanding of the phenotypic expression and cytogenetics of the $\mathrm{Y}$ chromosome in man.

We thank Dr E. B. Lewis of the California Institute of Technology and Dr J. Melnyk of the City of Hope, Duarte, California, for the fluorescent staining of metaphase and interphase chromosomes; Drs F. E. Arrighi and T. C. Hsu of the University of Texas at Houston for the heterochromatin staining; and $\mathrm{Dr} O$. W. Jones of the University of California School of Medicine (San Diego) for culturing the skin fibroblasts. Thanks are also due to Loma Linda University physicians, Dr H. Schone for reviewing the dermatoglyphics, Dr I. Kuhn for the bone marrow aspiration, and Drs W. Stilson and H. Gorman for interpreting the $x$-rays. We acknowledge the help of Dr J. H. Tjio of the National Institute of Health in reviewing the chromosome morphology, Dr G. Richardson for referring the patient, Dr G. Joy for obtaining various blood samples, and the outstanding cooperation of this boy and his family without which this report would not have been possible.

GERALD S. SCHOEPFLIN and WILLARD R. CENTERWALL*

Department of Pediatrics, Loma Linda University School of Medicine, California 92354, USA

\footnotetext{
* Our laboratory is supported in part by grants from the Walter E. Macpherson Society and The National Foundation-March of Dimes.
}

REFERENCES

Arrighi, F. E. and Hsu, T. C. (1971). Localization of heterochromatin in human chromosomes. Cytogenetics, 10, 81-86.

Berghe, H. van den, Verresen, H., and Cassiman, J. J. (1968). A :-

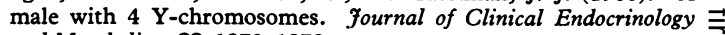
and Metabolism, 28, 1370-1372.

Caspersson, T., Zech, L., and Johansson, C. (1970). Analysis of human metaphase chromosome set by aid of DNA-binding fluorescent agents. Experimental Cell Research, 62, 490-492.

Cox, D. and Berry, C. L. (1967). A patient with $45 X O / 48 X Y Y Y$ mosaicism. Fournal of Medical Genetics, 4, 132-133.

Fraccaro, M., Taylor, A. I., and Bodian, M. (1962). A human intersex ('true hermaphrodite') with $\mathrm{XX} / \mathrm{XXY} / \mathrm{XXYYY}$ sex chromosomes. Cytogenetics, 1, 104-112.

Greulich, W. W. and Pyle, S. I. (1959). Radiographic Atlas of Skeletal Development of the Hand and Wrist. Stanford University Press, Stanford, California.

Lam-Po-Tang, P. R. L. C. (1968). An improved method of processing bone marrow for chromosomes. Scandinavian fournal of Haematology, 5, 158-160.

Moorhead, P. S., Nowell, P. C., Mellman, W. J., Battips, D. M., and Hungerford, D. A. (1960). Chromosome preparations of leukocytes cultured from human peripheral blood. Experimental Cell Research, 20, 613-616.

Pardue, M. L. and Gall, J. G. (1970). Chromosomal localization of mouse satellite DNA. Science, 168, 1356-1358.

Pearson, P. L., Bobrow, M., and Vosa, C. G. (1970). Technique for identifying $\mathrm{Y}$ chromosomes in human interphase nuclei. Nature, 226, 78-80.

Penrose, L. S. (1967). Finger-print pattern and the sex chromosomes. Lancet, 1, 298-300.

Townes, P. L., Ziegler, N. A., and Lenhard, L. W. (1965). A patient with 48 chromosomes (XYYY). Lancet, 1, 1041-1043.

Uchida, I. A., Ray, M., and Duncan, B. P. (1966). 21 Trisomy with an XYY sex chromosome complement. Fournal of Pediatrics, 69, 295-298.

Walker, N. F. (1958). The use of dermal configurations in the diag nosis of mongolism. Pediatric Clinics of North America, 5, 531 543.

\section{Immunoglobulin Abnormality in a Girl with a Large Chromosome 18}

Feingold et al (1968) first reported a case of IgA deficiency associated with partial deletion of the long arm of chromosome 18. Since then IgA deficiency has been reported in several patients with different abnormalities of chromosome 18 namely, partial deletion of the long arm, short arm deletion, and a ring 18 chromosome. Long arm deletion of chromosome 18 has been recognized as a clinical syndrome (de Grouchy, 1969). Chromosome 18 presumably has a locus for the production of $\operatorname{IgA}$, and deletion of part of this chromosome results in deficiency in an immunoglobulin $A$. Hecht (1969), however, reported a case of 18 trisomy associated with a striking deficiency of serum $\operatorname{IgA}$, and some reports had no IgA deficiency (Borgaonkar

Received 10 February 1972. 


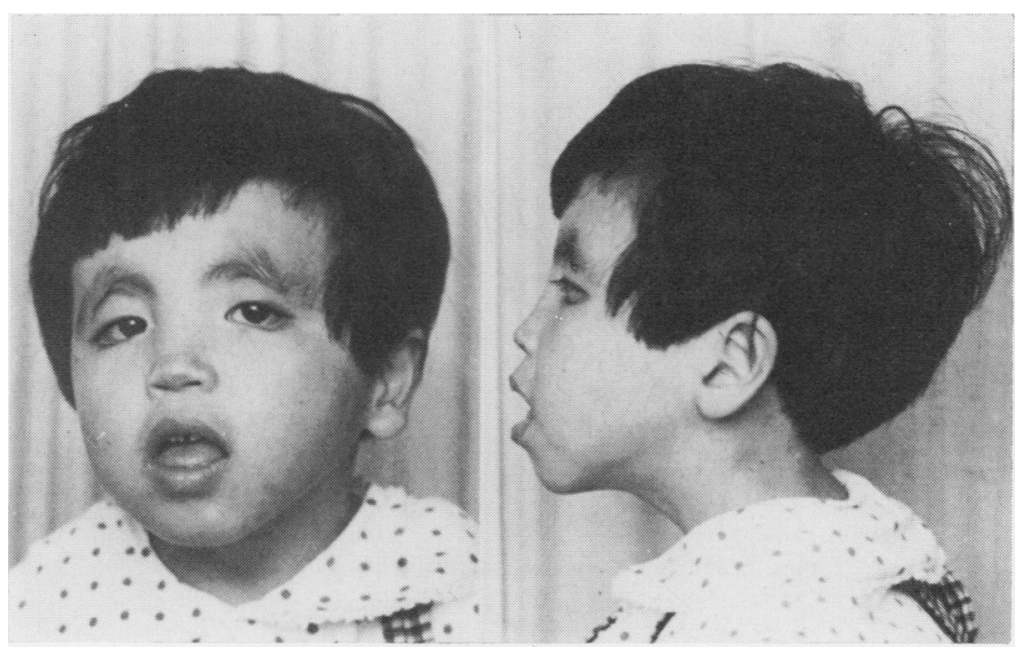

FIG. 1. Facial appearance of the patient.

et al, 1969; Haddad et al, 1969; Jensen et al, 1969; Christensen et al, 1970).

The patient reported here is a girl in whom an enlarged long arm of chromosome 18 is associated with deficiency in IgA. To our knowledge, this is the first example of a large chromosome 18 and abnormal IgA value. A preliminary note of cytogenetic findings on this case had been reported previously (Yanagisawa, 1971).

\section{Case Report}

The patient, who is now 13 years old, was first seen at 9 years of age because of mental and motor retardation. Her birth weight was $3200 \mathrm{~g}$. She had coiling of the umbilical cord and asphyxia was recognized at the time of birth. There was an episode of convulsions in the neonatal period. Physical measurements at 13 years of age were $127.7 \mathrm{~cm}$ in length (below $-3 \mathrm{SD}$ ), $28.0 \mathrm{~kg}$ in weight, head circumference $55.5 \mathrm{~cm}$. Her nonconsanguineous mother and father were both 23 years of age at the time of her birth, and there was no history of congenital defects or miscarriages in the immediate family.
Development of the patient was consistently delayed. She first walked alone at 3 years. She had severe mental and speech retardation.

Clinical features were as follows: short stature, prominent occiput, antimongoloid slant of the palpebral fissures, thick eyebrows, prominent nasal bridge, and lowset ears without abnormal helix. Her mouth was open and the tongue protruded (Fig. 1). There was a high arched palate but no mid-face aplasia. Joint involvements were recognized on wrist and ankle joints. Both 5th fingers were incurved. Finger and toe nails were hypoplastic. External genitalia were normally developed.

Immunological Studies. Serum immunoglobulins were quantified by immunoelectrophoresis. Immunoglobulin levels were as follows: IgG was $130 \mathrm{mg} / \mathrm{dl}$, IgA $35 \mathrm{mg} / \mathrm{dl}$, and IgM $195 \mathrm{mg} / \mathrm{dl}$, respectively. There were deficiency of IgA and moderate elevation of IgM.

Dermatoglyphic Findings. Finger-tip patterns revealed 4 whorls, 5 ulnar loops, and a radial loop. Total ridge count was 112 (Table I; Figs. 2a and 2b). There was no simian crease on the palms.

TABLE I

DERMATOGLYPHIC PATTERNS OF THE PATIENT

\begin{tabular}{|c|c|c|c|c|c|c|c|c|c|}
\hline & \multicolumn{5}{|c|}{ Finger-tip Patterns and Ridge Counts } & \multirow{2}{*}{$\begin{array}{l}\text { Ridge } \\
\text { Counts }\end{array}$} & \multirow{2}{*}{$\begin{array}{l}\text { a-b Ridge } \\
\text { Counts }\end{array}$} & \multirow{2}{*}{ atd Angle } & \multirow{2}{*}{$\begin{array}{c}\text { Hallucal } \\
\text { Area }\end{array}$} \\
\hline & I & II & III & IV & $\mathbf{V}$ & & & & \\
\hline Right & $\begin{array}{r}\mathrm{U} \\
11\end{array}$ & $\begin{array}{c}W \\
13,3\end{array}$ & $\begin{array}{l}\mathbf{U} \\
8\end{array}$ & $\begin{array}{c}W \\
16,14\end{array}$ & $\begin{array}{l}U \\
11\end{array}$ & 59 & 38 & $46^{\circ}$ & $\mathbf{L}^{\mathbf{d}}$ \\
\hline Left & $\begin{array}{c}W \\
6,6\end{array}$ & $\begin{array}{l}R \\
16\end{array}$ & $\begin{array}{l}\text { U } \\
9\end{array}$ & $\begin{array}{c}W \\
15,16\end{array}$ & $\begin{array}{l}U \\
6\end{array}$ & 53 & 50 & $55^{\circ}$ & $\mathbf{L}^{\mathbf{d}}$ \\
\hline
\end{tabular}



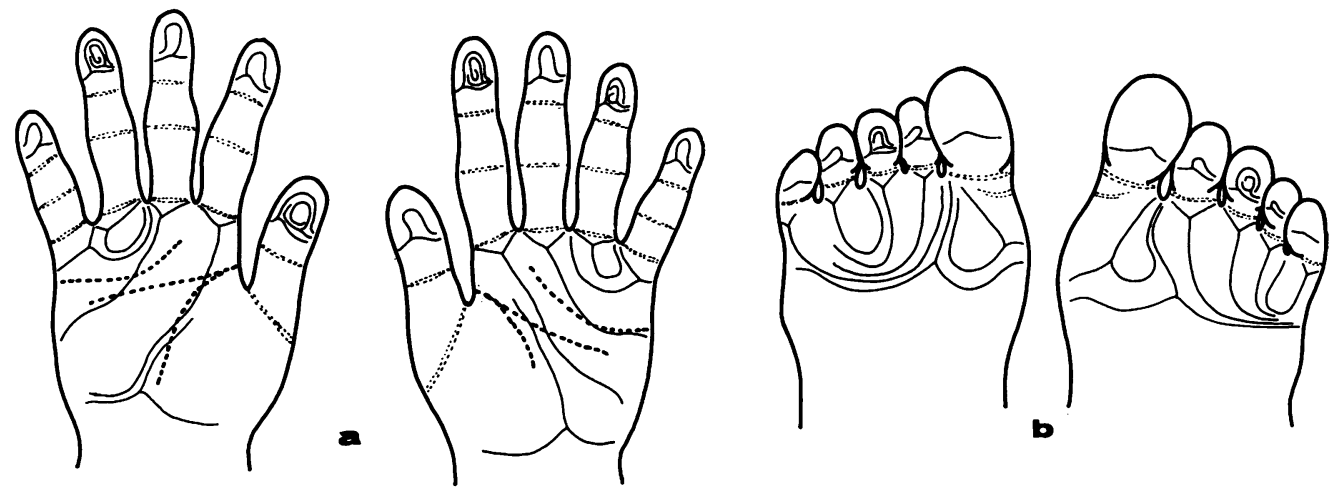

FIGs. 2a and 2b. Dermatoglyphic main lines of the patient.
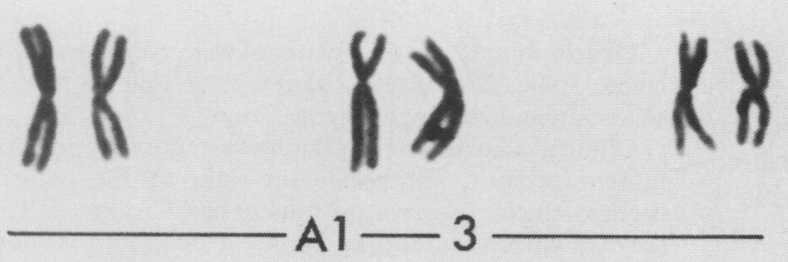

$-3$

\section{nQ An An} D13 $-15$

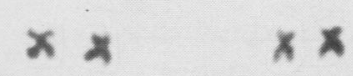

$\mathrm{F} 19-20$

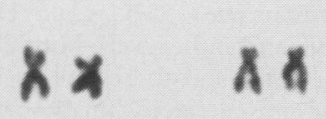

E16-18

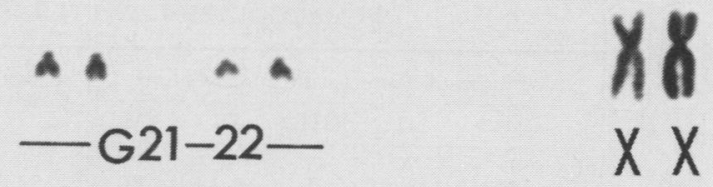

Fig. 3. Karyotype of the patient showing an abnormal long chromosome 18 (indicated by arrow). 

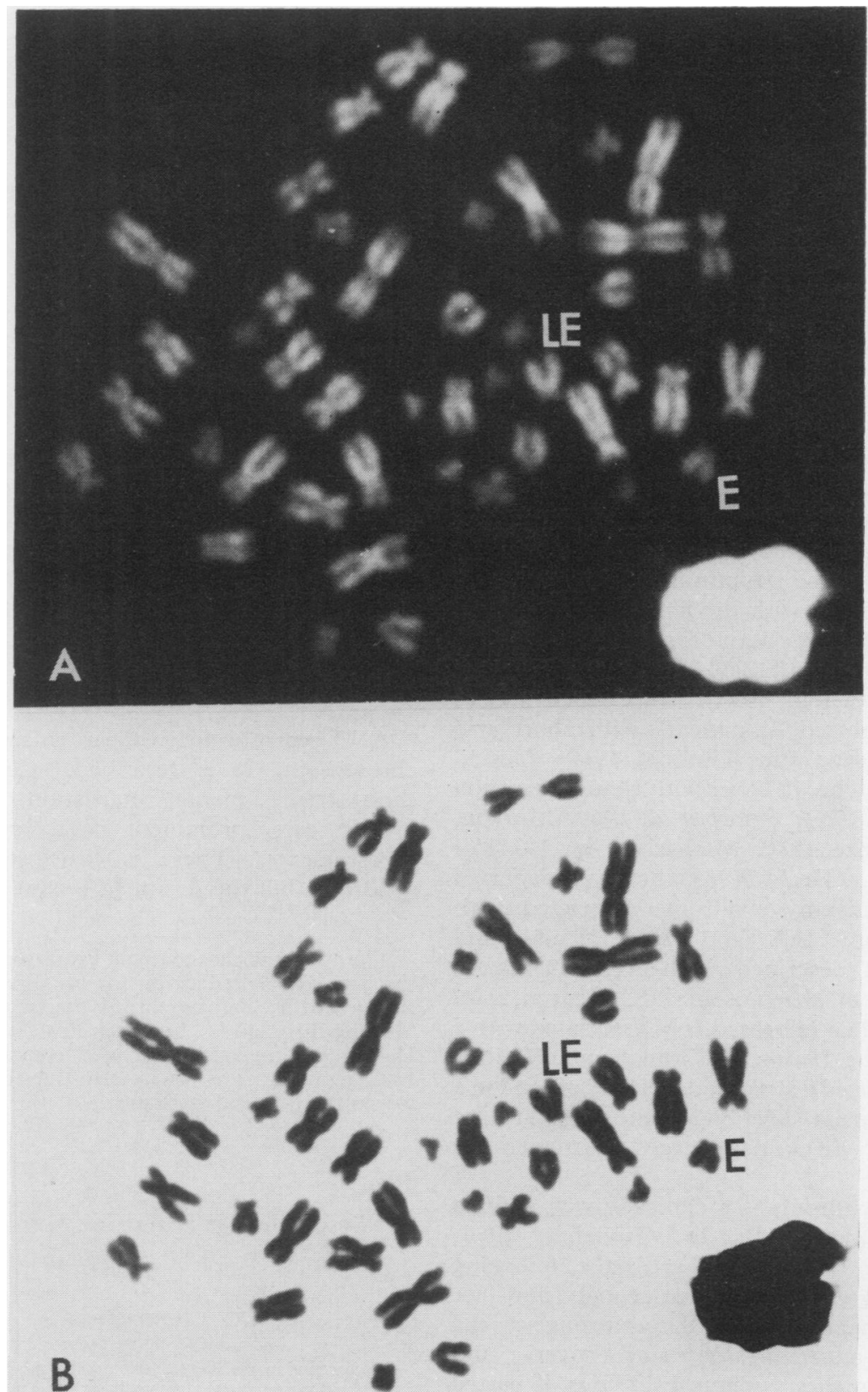

FIG. 4. Metaphase chromosomes stained with quinacrine dihydrochloride (A) and Giemsa (B). An abnormal chromosome is indicated by letters LE and a normal chromosome 18 by E. LE fluoresced more brightly than E. 
Cytogenetic Studies. Chromosome analyses were performed on leucocytes cultured from peripheral blood. The modal chromosome number was 46 and sex chromosome constitution was $\mathrm{XX}$, but one chromosome 18 had an enlarged long arm (Fig. 3).

Studies of fluorescence patterns on metaphase plates stained with quinacrine dihydrochloride (Borgaonkar and Hollander, 1970) were carried out. The abnormal chromosome 18 with the enlarged long arm fluoresced brightly. The other chromosome 18 appeared also brighter than chromosome 16 and 17 (Fig. 4).

Sex chromatin patterns in cells of the buccal mucosa were in agreement with her sex.

Chromosome analyses from the mother and two phenotypically normal sisters of the patient revealed normal karyotypes. The father is dead and therefore his karyotype was not available.

\section{Discussion}

Structural aberrations of chromosome 18 have been recognized as short arm deletion $(18 p-)$, long arm deletion $(18 q-)$, and ring formation (18r). Abnormal immunoglobin values have been reported in patients with these structural aberrations. IgA deficiency associated with the long arm deletion of chromosome 18 has been reported by several authors (Feingold et al, 1969; Stewart et al, 1970; Wertelecki and Gerald, 1971). IgA deficiency has also been recognized in patients with short arm deletion (Ruvalcaba and Thuline, 1969; Jansch, May, and LaMarche, 1970) or with a ring formation (Feingold et al, 1969; Finley et al, 1969; Murken, Salzer, and Kunze, 1970; Michaels et al, 1971) of chromosome 18. Hecht (1969), however, reported a case of 19 trisomy syndrome associated with decreased serum IgA and IgM. Rudd and LaMarche (1971) described a high level of IgA in the partial trisomy of chromosome 18. Jensen et al (1969) described an increased IgM associated with a ring chromosome 18; on the other hand, Haddad et al (1969) reported a striking deficiency of IgM in a patient with partial deletion of the long arm of chromosome 18. In our patient IgM was moderately increased.

The $18 \mathrm{q}$ - syndrome is a clinically well defined syndrome characterized (de Grouchy, 1969; Wertelecki and Gerald, 1971) by the following features: mental retardation, microcephaly, mid-face aplasia, carp-shaped mouth, hypertrophy of the antihelix and antitragus, tapering fingers, and ophthalmic anomalies. Clinical findings of partial 18 trisomy syndrome can not be distinguished from those of complete 18 trisomy syndrome except for long survival in partial trisomy (Rohde, Lee, and Sapin, 1963; Rudd and LaMarche, 1971).

Quinacrine fluorescence patterns of chromosome
18 appeared brighter than chromosome 16 and $17 \stackrel{\overbrace{}}{\complement}$ (Bobrow and Pearson, 1961; Cervenka, Jacobson, $\mathbb{D}$ and Gorlin, 1971). Therefore, there are 3 brightly $\stackrel{\oplus}{+}$ fluorescent No. 18 chromosomes in trisomy $18 \Rightarrow$ syndrome (S. Yanagisawa, unpublished data). However, the long arm of the abnormal chromosome 18 in this patient stained with quinacrine dihydrochloride fluoresced more brightly than the normal chromosome 18.

The phenotype of the patient appears to be closer $\&$ to that of 18 trisomy syndrome rather than $18 \mathrm{q}-\overrightarrow{0}$ syndrome. However the result of quinacrine fluorescence study suggests that the abnormal $\vec{\omega}$ chromosome could be the result of a reciprocal translocation between a chromosome 18 and an unknown chromosome resulting in partial monosomy 6 of the long arm of chromosome 18 and a trisomic state of unknown material.

Immunoglobulin A deficiency in this case was interpreted as the result of the long arm deletion of chromosome 18 due to reciprocal translocation. Clinical features of the patient revealed few stigma of the 18q - syndrome and these could be interpreted as due to the trisomic state of a chromosome segment of unknown origin.

\section{Summary}

A 13-year-old girl with an enlarged long arm of chromosome 18 is described. Clinically she hat short stature, mental retardation, thick eyebrows, low-set ears, prominent nasal bridge, and joint involvements. There is little stigma of $18 q-$ syndrome but the serum IgA value was decreased.

The author wishes to thank Professor Shunzo Konishi, Department of Pediatrics, for his direction and Drs Y. Katoh and Y. Yamaguchi for their cooperation in performing this study. Emeritus Professor Sajiro Makino, Hokkaido University, provided constant help and encouragement. Thanks are also due to Miss S. Iwasaki for skilful technical assistance.

SATOShi YaNAGisawa

Department of Pediatrics, Yamaguchi University School of Medicine, Ube, Fapan REFERENCES

Bobrow, M. and Pearson, P. L. (1971). The use of quinacrine fluorescence in the identification of $B$ and $\mathbf{E}$ group chromosomes involved in structural abnormalities. Fournal of Medical Genetics, 8, 240-243.

Borgaonkar, D. S., Bias, W. B., Scott, C. I., Wadia, R. S., and Borkowf, S. P. (1969). IgA and abnormal chromosome 18. Lancet, 1, 206-207.

Borgaonkar, D. S. and Hollander, D. H. (1970). Quinacrine fluorescence of the human $\mathrm{Y}$ chromosome. American fournal of Human Genetics, 22, 23a. 
Červenka, J., Jacobson, D. E., and Gorlin, R. J. (1971). Fluorescing structures of human metaphase chromosomes. Detection of 'Y body'. American fournal of Human Genetics, 23, 317-324.

Christensen, K. R., Friedrich, U., Jacobsen, P., Jensen, K., Nielsen, J., and Tsuboi, T. (1970). Ring chromosome 18 in mother and daughter. Fournal of Mental Deficiency Research, 14, 49-67.

De Grouchy, J. (1969). The $18 \mathrm{p}-, 18 \mathrm{q}-$ and $18 \mathrm{r}$ syndromes. Birth Defects: Original Article Series, V, 5, pp. 74-87. National Foundation-March of Dimes, New York.

Feingold, M., Schwartz, R. S., Atkins, L., Anderson, R., Bartsocas, C. S., Page, D. L., and Littlefield, J. W. (1968). IgA deficiency associated with partial deletion of chromosome 18. Fournal of Clinical Investigation, 47, 34a.

Feingold, M., Schwartz, R. S., Atkins, L., Anderson, R., Bartsocas, C. S., Page, D. L., and Littlefield, J. W. (1969). IgA deficiency associated with partial deletion of chromosome 18. American fournal of Diseases of Children, 117, 129-136.

Finley, S. C., Cooper, M. D., Finley, W. H., Uchida, I. A., Noto, T. A., and Roddam, R. F. (1969). Immunological profile in a chromosome 18 deletion syndrome with IgA deficiency. fournal of Medical Genetics, 6, 388-393.

Haddad, Z. H., Allen, R. F., Towner, J. W., and Wilson, M. G. (1969). IgA, IgM, and partial deletion of chromosome 18. Lancet, 1, 678 .

Hecht, F. (1969). IgA and partial deletions of chromosome 18. Lancet, 1, 100-101.

Jansch, M. E., May, J. B., and LaMarche, P. H. (1970). $18 \mathrm{p}-/ \mathrm{Gq}$ - mosaicism in a girl with absent IgA. Case represents an unusual mosaicism of two rare genetic anomalies. Rhode Island Medical fournal, 53, 623-625.

Jensen, K., Christensen, K. R., Jacobsen, P., Nielsen, J., Friedrich, U., and Tsuboi, T. (1969). Ring chromosome 18 and gammaM-globulin abnormality. Lancet, 2, 497-498.

Michaels, D. L., Go, S., Humbert, J. R., Dubois, R. S., Stewart, J. M., and Ellis, E. F. (1971). Intestinal nodular lymphoid hyperplasia, hypogammaglobinemia, and hematologic abnormalities in a child with a ring 18 chromosome. Fournal of Pediatrics, 79, 80-88.

Murken, J. D., Salzer, G., and Kunze, D. (1970). Ringchromosom Nr. 18 und fehlendes IgA bei einem 6 jährigen Mädchen $(46, \mathrm{XX}$, 18r). Zeitschrift für Kinderheilkunde, 109, 1-10.

Rohde, R. A., Lee, A., and Sapin, S. (1963). A new trisomytranslocation chromosome (long-arm E/E). Lancet, 2, 13091310.

Rudd, N. L. and Lamarche, P. H. (1971). Gene deletion and duplication effects on phenotype and gamma globulin levels. Fournal of Medical Genetics, 8, 97-106.

Ruvalcaba, R. H. A. and Thuline, H. C. (1969). IgA absence associated with short arm deletion of chromosome No. 18. Fournal of Pediatrics, 74, 964-965.

Stewart, J. M., Go, S., Ellis, E., and Robinson, A. (1970). Absent IgA and deletions of chromosome 18. Fournal of Medical Genetics, 7, 11-19.

Wertelecki, W. and Gerald, P. S. (1971). Clinical and chromosomal studies of the $18 \mathrm{q}$ - syndrome. Fournal of Pediatrics, 78, 44-52.

Yanagisawa, S. (1971). A case of $18 q+$ in a girl with severe mental retardation. Chromosome Information Service (Tokyo), no. 12, 1213.

\section{A Double Aneuploid Mosaic: Trisomy 13 and $\mathrm{XXY}^{*}$}

We have examined a liveborn male who showed physical features of trisomy 13 syndrome and was

Received 22 February 1972

- This study was supported in part by Grant 286 from Maternal and Child Health Service, United States Public Health Service. found to have $47, \mathrm{XY}, 13+/ 48, \mathrm{XXY}, 13+$ mosaicism. To our knowledge, this is the first report of trisomy 13 and an XXY sex chromosome complement coexisting in a liveborn individual.

\section{Case Report}

The patient, a Caucasian male, was born to a 17 -yearold primigravida mother and a 19-year-old father. The father had a son by a prior union. The remainder of the pedigree was unremarkable. Both parents had taken lysergic acid diethylamide (LSD) 2 years before the pregnancy. The infant was the product of an apparently normal 36-week gestation and vertex delivery. Birth weight was $1480 \mathrm{~g}$, length $42 \mathrm{~cm}$, and head circumference $29 \mathrm{~cm}$. The anterior fontanelle was large; the sagittal suture was $1 \mathrm{~cm}$ in each diameter. There was a bony defect $1.6 \times 2 \mathrm{~cm}$ in the parieto-occipital region through which the meninges were seen (Fig. 1). The parietal bones overlapped the frontal and occipital bones. The face had an inverted triangular shape with a broad forehead and hypoplastic left eye (Fig. 2). The right eye was normal. The nose was large and prominent, the mouth was small and the ears were low set. The neck showed redundant skin folds. There was a ventral hernia 1.5 $\mathrm{cm}$ above the umbilicus. Except for an undescended left testis, the genitalia were normal for a male infant. Both hands had a simian crease and an extra ulnar digit. The feet were rocker bottom in shape and showed a wide space between the 1st and 2nd toes. The remainder of the physical examination was normal. The infant was alert, cried vigorously, and showed no abnormal neurological findings. Shortly after admission he became cyanotic and was given antibiotics for suspected

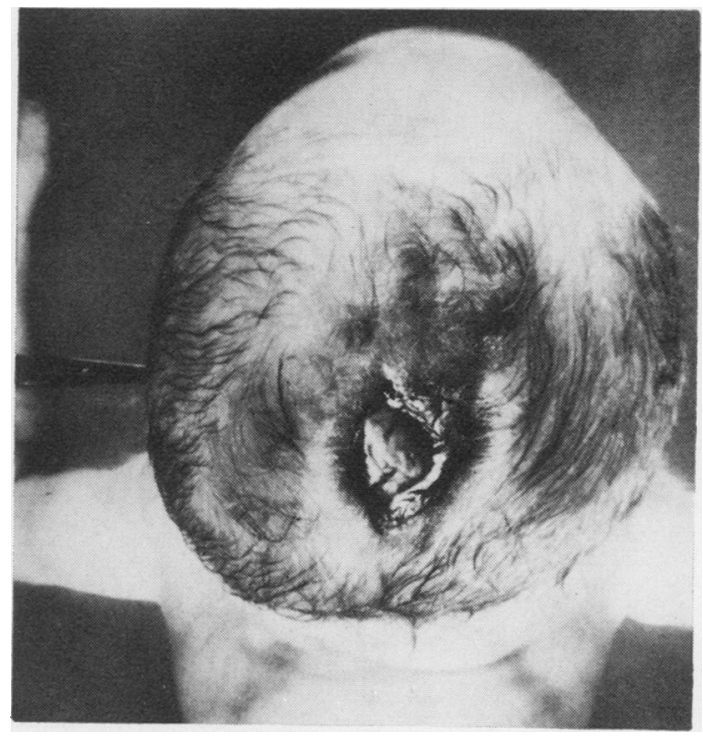

Fig. 1. Scalp view of the propositus. 